\title{
1.2. ОЦЕНКА НАЛОГОВОГО ПОТЕНЦИАЛА РЕГИОНОВ В ЦЕЛЯХ ПОВЫШЕНИЯ БЮДЖЕТНОЙ УСТОЙЧИВОСТИ СУБЪЕКТОВ РОССИЙСКОЙ ФЕДЕРАЦИИ
}

Яшина Н.И., д.э.н., профессор,

заведующий кафедрой финансов и кредита;

Жильцова Ю.В., к.э.н.,

доцент кафедры судебной экспертизы;

Жильцова А.В., магистрант 2-го курса

ФГАОУ ВО «Национальный исследовательский Нижегородский государственный университет им. Н.И. Лобачевского», г. Нижний Новгород

Принципы и методы анализа налогового потенциала в целях управления финансовой устойчивостью регионов являются актуальной тематикой для теоретических и практических исследований, так как в настоящее время сложнейшими стратегическими задачами экономической политики являются выравнивание уровня развития субъектов Российской Федерации и выполнение национальных проектов на всей территории РФ. Налоговый потенциал является важнейшим показателем для оценки экономической безопасности государства и его субъектов. Кроме того, налоговый потенциал - это комплексный макроэкономический показатель, что усложняет его расчеты и объективную оценку. В данной статье рассматривается авторская методика оценки налогового потенциала регионов на основе публичной информации Федеральной службы государственной статистики, представлены результаты рассчитанного рейтинга и выводы. Выявлена обязательность нормативого установления ряда важных дефиниций.

\section{Литература}

1. Конституция РФ от 12.12.1993 (с учетом поправок от 30.12.2008 №6-ФКЗ, от 30.12.2008 №7-ФК3, от 05.02.2014 №2ФКЗ, от 21.07.2014 №11-ФКЗ) [Электронный ресурс]. Доступ из справ.-правовой системы «КонсультантПлюс».

2. Бюджетный кодекс РФ [Электронный ресурс]: от 31 июля 1998 г. №145-Ф3 (ред. от 2 авг. 2019 г.) (с изм. и доп., вступ. в силу с 12 нояб. 2019 г. №367-Ф3). Доступ из справ.-правовой системы «Консультант Плюс».

3. Налоговый кодекс РФ [Электронный ресурс]: часть первая от 31 июля 1998 г. №146-Ф3 (ред. от 6 июня 2019 г. №125Ф3.). Доступ из справ.-правовой системы «КонсультантПлюс».

4. О национальных целях и стратегических задачах развития РФ на период до 2024 г. [Электронный ресурс]: Указ Президента РФ от 7 мая 2018 г. №204. Доступ из справт-правовой системы «Консультант Плюс».

5. О распределении дотаций на выравнивание бюджетной обеспеченности субъектов РФ (вместе с Методикой распределения дотаций на выравнивание бюджетной обеспеченности субъектов РФ) [Электронный ресурс]: постановление Правительства РФ от 22 нояб. 2004 г. №670 (ред. от 27 дек. 2019 г. №1903). Доступ из справ.-правовой системы «КонсультантПлюс».

6. О транспортном налоге [Электронный ресурс] : Закон Нижегородской области от 28 нояб. 2002 г. №71-3 (ред. от 11 нояб. 2019 г. №143-3 ). Доступ из справ.-правовой системы «Кодекс».

7. О налоге на имущество организаций [Электронный ресурс]: Закон Нижегородской области от 27 нояб. 2003 г. №109-3 (ред. от 28 нояб.2019 г. №145-3, №146-3). Доступ из справ.-правовой системы «Кодекс».

8. О налоге на игорный бизнес [Электронный ресурс] : Закон Краснодарского края от 20 нояб. 2003 г. №611-КЗ (ред. от. 25 дек. 2017 г. №3724-КЗ). Доступ из справ.-правовой системы «Кодекс».

9. Об утверждении Стратегии развития Ненецкого автономного округа до 2030 года [Электронный ресурс]: постановление Собрания депутатов Ненецкого автономного округа от 7 нояб. 2019 г. №256-с. Доступ из справ.-правовой системы «Кодекс».

10. Ананиашвили Ю.Ш. Налоги и макроэкономическое равновесие лафферо-кейнсианский синтез [Текст] / Ю.Ш. Ананиашвили, В.Г. Папава. - Стокгольм: CA\&CC Press, 2010. - 142 c.

11. В России всего три региона-донора, остальные дотационные или банкроты [Электронный ресурс] // Царьград: сетевое издание. - URL : https://tsargrad.tv/ articles/v-rossii-vsego-tri-regiona-donora-ostalnye-dotacionnye-ili-bankroty_131121.

12. Глазьев С.Ю. О стратегии и концепции социально-экономического развития России до 2020 года [Текст] / С.Ю. Глазьев // Конкурентная политика. - 2008. - №5. - С. 28-42.

13. Жильцова Ю.В. Анализ финансового обеспечения социальной политики современной России [Текст] / Ю.В. Жильцова, А.В. Жильцова // Аудит и финансовый анализ. - 2019. - №2. - С. 176-179.

14. Иванов В.В. Налоговый потенциал региона как фундамент бюджетной системы страны [Текст] / В.В. Иванов // Проблемы современной экономики. - 2014. - №2. - С. 204-207.

15. Кузьменко В.В. Институциональный подход к исследованию налогового потенциала и налогового бремени [Текст] / В.В. Кузьменко, Е.А. Ефимец // Сб. науч. тр. СевКавГТУ; Сер : Экон. -- 2005. - №1. - С. 30-49.

16. Матрусов Н.Д. Региональное прогнозирование и региональное развитие России [Текст] / Н.Д. Матрусов. - -М. : Наука, 1995. -219 c.

17. Можно ли найти в России в 2019 году действующие игорные зоны [Электронный ресурс] // Новости России и СНГ: официальное издательство. - URL: http://rusdni.ru/ekonomika/novosti/mozhno-li-najti-v-rossii-v-2016-2017-godudejstvuyushhie-igornye-zony.html.

18. Отчет губернатора XМАО-Югры о результатах деятельности Правительства за 2017 г. [Электронный ресурс]. - URL : https://depeconom.admhmao.ru/upload/medialibrary/ 39b/otchyet-gubernatora-2017.pdf.

\footnotetext{
${ }^{1}$ Исследование выполнено при финансовой поддержке Российского Фонда Фундаментальных исследований в рамках научного проекта 18-010-00909 A.
} 
19. Паскачев А.Б. Моделирование деловых процессов в налоговых инспекциях: монография [Текст] / А.Б. Паскачев, Ю.Д. Джамурзаев. - М. : Изд-во экон.-прав. лит-ры, 2006. - 304 с.

20. Регионы России. Социально-экономические показатели [Электронный ресурс]: 2018 / Федер. служба гос. стат. - URL: http://www.gks.ru/free_doc/doc_2018/region/reg-pok18. pdf.

21. Россия в цифрах [Электронный ресурс] : 2018 / Федер. служба гос. стат. - URL : http://www.gks.ru/free_doc/ doc_2018/rusfig/rus18.pdf.

22. Сенчагов В.К. Структура механизма современного мониторинга экономической безопасности России [Текст] / В.К. Сенчагов. - М. : ИЭ, 2016. - $71 \mathrm{c}$.

23. Стратегия социально-экономического развития ЯНАО до 2030 г. [Электронный ресурс] : проект. - URL : http:// economy.gov.ru/wps/wcm/connect/7a0a6326-40b4-4467-a6b2-f6850984af1c/strategyamal.pdf?MOD=AJPERES\& CACHEID=7a0a6326-40b4-4467-a6b2-f6850984af1c.

24. Стратегия-2020: Новая модель роста - новая социальная политика [Электронный ресурс]: в 2 кн. Книга $1 /$ под ред. B.A. Мау, Я.И. Кузьминова. - URL: https://www.ranepa.ru/ docs/Nauka_Konsalting/strategia-2020_kniga-1.pdf.

25. Яшина Н.И. и др. Методологические подходы к оценке эффрективности бюджетного контроля в современных условиях реформирования бюджетной системы РФ [Текст] / Н.И. Яшина, Е.В. Поющева, А.В. Комиссаров // Финансы и кредит. 2012. - №44. - C. 10-15.

26. RAEX: опубликован рейтинг регионов России с максимальным производственным потенциалом [Электронный ресурс]. URL: https:// https://raex-a.ru/releases/2019/Jan18

\section{Ключевые слова}

Экономическая политика РФ; федеральные налоги; региональные налоги; бюджетная система; распределение налогов между бюджетами; налоговый потенциал; методика оценки бюджетной устойчивости; рейтинг регионов; лидеры и аутсайдеры.

\section{Яшина Надежда Игоревна \\ Жильцова Юлия Валерьевна \\ Жильцова Алина Валерьевна}

\section{РЕЦЕНЗИЯ}

Статья посвящена авторской методике оценки налогового потенциала субъектов Российской Федерации как важного макроэкономического показателя

Выравнивание развития регионов РФ является стратегической задачей государственной экономической политики в целях роста национальной экономики и достижения высоких социальных показателей. Разработка принципов и методов оценки налогового потенциала регионов способствует решению проблемы зависимости роста налогооблагаемой базы от уровня социально-экономического развития федеративного субъекта и, в том числе, повышению бюджетной устойчивости. Все это свидетельствует об актуальности, научной и практической значимости данной статьи.

В статье рассмотрено содержание актуальной правовой базы, а также использованы данные официальной статистики по регионам и округам РФ за 2017 г. Раскрыто содержание понятия «налоговый потенциал». Предложенная методика оценки регионов позволяет группировать их по уровню налогового потенциала. Теоретические разработки авторы подкрепляют расчетами, по результатам которых сформирован дифференцированный рейтинг и установлены лидеры и аутсайдеры среди субъектов РФ. Материал статьи содержит множество таблиц, составленных авторами.

Общий вывод: научная статья Н.И. Яшиной, Ю.В. Жильцовой, А.В. Жильцовой «Оценка налогового потенциала регионов в целях повышения бюджетной устойчивости субъектов Российской Федерации» имеет научную и практическую ценность, содержит элементы научной новизны, может использоваться при проведении научных исследований, на практике при составлении плановых бюджетов, а также в учебном процессе высшей школы, материал изложен профессионально и соответствует всем требованиям, предъявляемым к работам такого рода. Научная статья рекомендуется к публикации в журнале «Аудит и финансовый анализ», входящем в перечень Высшей аттестационной комиссии

Козменкова С.В., Ә.э.н., профрессор, профессор кафедры «Судебная экспертиза» Юридического фракультета ФГАОУ ВО «Национальный исследовательский Нижегородский государственный университет им. Н.И. Лобачевского», г. Нижний Новгород

DOI 10.38097/AFA.2020.99.77.002 